\title{
Correspondence
}

\author{
Letters to the Editor should not exceed 500 words.
}

\author{
Hong Kong Influenza \\ B. D. Apthorp, M.R.C.P. ..................49 \\ Chest Physicians \\ W. D. W. Brooks, F.R.C.P., and others .....49 \\ Radiation Hazards of High Altitude Flight \\ J. F. Loutit, F.R.C.P., F.R.S. ..................50 \\ Factors in Host-Virus Relationship \\ Constance A. C. Ross, M.D. ................50 \\ Inhibition of Lactation with Oestrogens \\ C. K Vartan, F.R.C.o.G. ; D. D. Brown, \\ M.D. ; S. McPherson, M.B., D.oBST.R.C.o.G. 50 \\ Polyglutamyl Forms of Folate Acid in Man \\ A. V. Hoffbrand, M.R.C.P. ..................51 \\ Malignant Renal Lesions and Erythrocytosis \\ M. A. Sperber, M.D. ….................51 \\ Dipyridamole in Acute Myocardial Infarction \\ M. Friedemann, M.D. .......................52 \\ Sheepskins and Tetanus \\ D. C. Cowling, F.R.A.C.P., and others .....52 \\ Fibrinolytic Activity and Sickle-cell Crises \\ A. Mahmood, PH.D., M.R.C.P.ED. ...........52 \\ Hiatus Hernia \\ W. Silber, F.R.C.S.ED. ....................53
}

Treatment of Skin Fissures

Lieutenant-Colonel H. C. M. Walton, M.B. 53

Tests for Hearing

H. S. Sharp, F.R.c.s. ...................53

E.C.G. in Diagnosis

J. Horton, M.B. ...........................5

Keloids

G. Holmes, F.R.C.S. ....................53

Intravenous Penicillin

H. Smith, M.R.C.P., and S. E. J. Young,

M.B. ...................................5 53

Training of Surgeons

O. Gish .............

Alcohol and Drugs
G. E. Philip, M.B.

...........................54

G. E. Philip, M.B.

D. Pickering, M.R.C.P.ED. ...............54

Insanity and Tumours

Adelola Adeloye, M.R.C.P., and others .....54

Bilateral Parietal Thinning in Bronze Age

P. C. Dutta, M.B.

Dr. Thomas Percival and Jane Austen

Sir Zachary Cope, M.S., F.R.C.s. ..............55
Bladder Distension Causing Oedema of Legs

B. Balakrishna, M.B. ......................56

Solvents for Ear Wax

H. Godfrey, M.P.S. .......................56

Adversity

G. Moses, M.B. ...........................56

Medical Immigration

A. J. Akhtar, M.R.C.P.ED. ....................56

Salaried Service

J. F. G. Pigott, м.в. ....................57

Recognition for Seniority

E. R. C. Walker, F.R.C.P.

. .57

British Doctors in North America

E. O. Evans, м.в. ........................57

Green Paper

Rosemary A. Hill, M.B. ; Mervyn Goodman,

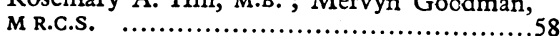

Medical Assistants

I. M. Librach, D.P.H. ......................58

S.H.M.O. Grade

N. Strang, M.B. ...........................58

Joint Consultants Committee

G. G. Muir, M.D. .........................58

Doctors and Patients

Doctors and Patients
Alma Hale-White

(1)

\section{Hong Kong Influenza}

SIR,-It occurs to me that some medical practitioners may be interested to hear of my recent experience dealing with an epidemic of Hong Kong influenza.

The outbreak occurred during the month of September-October in a 30,000-ton liner cruising in the Pacific (Sydney, Honolulu, North America, Honolulu, Japan, Hong Kong, Sydney). There were 700 crew members, and about 1,400 passengers. In all I saw approximately 200 cases among the passengers, 80 among the crew, and 15 officers. There were probably considerably more milder cases who did not consult me or my assistant.

The onset of the illness was identical in nearly every case. The patient complained of a headache. This was so severe that the phrase " $i$ feels as if the top of my head is lifting off "was constantly used. The temperature was usually in the region of $101-102^{\circ} \mathrm{F}$. $\left(38-39^{\circ} \mathrm{C}\right.$.), the highest being $105^{\circ}$ F. $\left(41^{\circ}\right.$ C.). There was a characteristic violaceous colour to the oropharynx. Despite the severe headaches there were no physical signs suggestive of meningism

None of the cases presented in a state of shock, as was suggested might happen in your leading article (14 December, p. 655). Several elderly patients presented with a severe toxic psychosis, the disorientation doubtless being enhanced by the strange surroundings of the ship. Europeans seemed to withstand the condition better than the Asian crew, many of whom

remained ill for a considerable time. Elderly patients showed a predisposition to complications. It is interesting to note that neither myself, my assistant, or two nursing sisters developed the disease.

The majority of patients developed a cough, and I estimate that as many as $60 \%$ of the patients that I saw developed frank bronchitis with purulent sputum. Only a handful developed signs suggestive of pneumonia. Though some patients responded to aspirin and linctus codein., many required antibiotics-tetracycline being the one usually administered.

I am sure that the problem for the general practitioner will be whether to administer tetracycline $a b$ initio. The feeling of most of my Australian colleagues would seem to be that in this epidemic the majority of cases develop a bronchitis, which is only brought under control by broad-spectrum antibiotics; this being so, the earlier they are given the better. The contrary view is that the early exhibition of tetracycline might lead to a tetracycline-resistant infection.

On the ship it was easy to see patients twice daily, and judge each case on its merits. This would almost certainly not be possible in general practice. Doubtless if the epidemic comes there will be two camps-the early and the late tetracycline prescribers. - I am, etc.
London E.1.
B. D. APthoRp.

\section{Chest Physicians}

SIR,-You published a Table (Supplement, 14 September, p. 110) showing the numbers of doctors in posts above house officer grade in N.H.S. hospitals and in general practice. This Table, provided by the Ministry of Health, included comments on the prospects in the various specialties. We wish to draw attention to the discrepancy between the Medical Advisory Committee to report on chest clinics in relation to the rest of the hospital services. The report of this subcommittee, of which one of us was chairman, was endorsed by the Central Health Services Council. It was published by the Ministry in July 1968, and commended to hospital authorities by the Minister in H.M.(68) 45 . The report drew attention to the fact that respiratory diseases remain, and are likely for the foreseeable future to remain, prominent among causes of death and disability, being the stated cause of about $16 \%$ of deaths in England and Wales, and the commonest cause of absence from work for sickness. It recommended that the current trend towards the incorporation of chest clinics in general hospitals should be encouraged, and that " as new hospitals are built and old hospitals redeveloped, provision should be made for the work of chest clinics ... to be incorporated as part of the activities of the genera hospital" (para. 14). Moreover, "the medical staffing of the chest department ... should follow the general pattern of staffing appropriate to other special departments. The consultant should be called 'physician to the chest department" (para. 18).

The report further considered both the special facilities required for such a department and the special training required by the consultant. It follows from these recommendations that a physician with special training in diseases of the chest will be required in every district general hospital If we accept the estimate that one district hospital should provide for every 120,000 population, we may conclude that 400 physicians in charge of chest departments will be required in England and Wales, on a population estimate of 48 million Additionally, one or more specialized thoracic units will continue to be required in each region (para. 17). Each of these will require at least one specialized physician. Presumably physicians with special training in chest diseases will continue to be required also in teaching hospitals. The desirable number of physicians specializing in chest diseases may 